IRA-International Journal of Education \& Multidisciplinary Studies

ISSN 2455-2526; Vol.08, Issue 01 (July 2017)

Pg. no. 142-148

Institute of Research Advances

http://research-advances.org/index.php/IJEMS

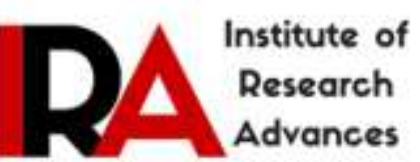

\title{
Demographic Factors Affecting Teachers' Job Satisfaction and Performance in Private Primary Schools in Yei Town, South Sudan
}

\author{
Alyaha Daniel Felix Ohide \\ Principal, Emmanuel Cristian College, Goli - Yei, South Sudan \\ c/o Open Doors, P. O. Box 30870 - 00100, Nairobi, Kenya. \\ Rosemary Wahu Mbogo" \\ Lecturer, Education Department; and \\ Dean of the School of Education, Arts and Social Sciences (SEAS) \\ Africa International University, P.O. Box 24686 - 00502 Karen, Nairobi, Kenya.
}

Type of Review: Peer Reviewed. "

DOI: http://dx.doi.org/10.21013/jems.v8.n1.p14

\section{How to cite this paper:}

Alyaha, D.O., Mbogo, R.W. (2017). Demographic Factors Affecting Teachers' Job Satisfaction and Performance in Private Primary Schools in Yei Town, South Sudan. IRA International Journal of Education and Multidisciplinary Studies (ISSN 2455-2526), 8(1), 142-148. doi: http://dx.doi.org/10.21013/jems.v8.n1.p14

(C) Institute of Research Advances.

\section{(cc) BY-No}

This work is licensed under a Creative Commons Attribution-Non Commercial 4.0 International License subject to proper citation to the publication source of the work.

Disclaimer: The scholarly papers as reviewed and published by the Institute of Research Advances (IRA) are the views and opinions of their respective authors and are not the views or opinions of the IRA. The IRA disclaims of any harm or loss caused due to the published content to any party.

Institute of Research Advances is an institutional publisher member of Publishers Inter Linking Association Inc. (PILA-CrossRef), USA. The institute is an institutional signatory to the Budapest Open Access Initiative, Hungary advocating the open access of scientific and scholarly knowledge. The Institute is a registered content provider under Open Access Initiative Protocol for Metadata Harvesting (OAI-PMH).

The journal is indexed \& included in WorldCat Discovery Service (USA), CrossRef Metadata Search (USA), WorldCat (USA), OCLC (USA), Open J-Gate (India), EZB (Germany) Scilit (Switzerland), Airiti (China), Bielefeld Academic Search Engine (BASE) of Bielefeld University, Germany, PKP Index of Simon Fraser University, Canada. 


\begin{abstract}
Job satisfaction is an important construct to the field of organizational behavior and the practice of human resource management. Schools are no exception to the list of organizations ensuring teachers' job satisfaction therefore becomes inevitable if schools have to record good performances. This paper aims at examining some of the demographic factors affecting job satisfaction of teachers in private primary schools and their consequent performance. To attain this objective; the authors carried out a survey study in private schools in Yei town, South Sudan. Simple random sampling technique was used to select the respondents from ten private schools in the town. A total of 110 respondents were considered for the study constituting 10 head teachers and 100 teachers from each of the 10 schools. Questionnaires were used for data collection. Data was then analysed by the use of Statistical Package for Social Science (SPSS) version 12.0 and presented in frequencies and percentages. The factors identified included gender, age bracket, educational level, pay and length of service of teachers. Based on the findings, it is apparent that certain demographic factors have a significant influence on the level of job satisfaction of teachers in private schools.
\end{abstract}

Key words: Job satisfaction, Demographics, Private primary schools, Teachers, Performance.

\title{
Introduction
}

Performance of teachers mainly depends on the teacher characteristics such as knowledge base, sense of responsibility and inquisitiveness; the student characteristics such as opportunity to learn and academic work; the teaching factors such as lesson structure and communication; the learning aspects such as involvement and success; and the classroom phenomena such as environment and climate, and organization and management [1]. Teacher performance can be enhanced to the optimum level if the government and related stakeholders take care of these factors. However, alternatives put into practice by states and districts to determine teacher quality have been dolefully not enough. Teacher entrance and exit, examination scores, teaching credentials, advanced degrees and years of experience are neither related to student achievement and ratings of teacher effectiveness [2].

According to Schmidt, the quality of teaching has come down gradually all over the world, which demonstrates that the skills of teachers have come down due to outdated preparation on the part of the teacher and stagnant compensation schemes by the educational institution management [3]. This condition in the recent years for the teacher has led to inadequate compensation structure and very few growth opportunities. Hence, with disadvantaged students who require excellent teachers but have the least, the condition has continued to be worse.

Previous studies conducted in various countries on the phenomenon of job satisfaction reveal age and gender factors. For example, a study conducted among Canadian teachers revealed that job satisfaction levels differ significantly between male and female teachers [4]. Similarly, the results of a study that was conducted in the United States by Bishay revealed that there were significant differences in the levels of job satisfaction between male and female teachers [5]. Although both studies indicated that female teachers were more satisfied with their job than male teachers, Zhongshan [6] found that elementary school male teachers in Shanghai, China were more satisfied with their salaries than their female colleagues. Conversely, Crossman and Harris found that satisfaction levels among secondary school teachers in the United Kingdom did not differ significantly by gender [7].

Previous research data collected in various countries give mixed results about the influence of age on job satisfaction. Findings of a study conducted among teachers in Finland revealed that there was a strong relationship between the teachers' age and job satisfaction [8]. The Finnish secondary school teachers assessed established that teachers' job satisfaction was linked to their age. On the contrary, Crossman and Harris [7] found that secondary school teachers in United Kingdom did not differ significantly in their job satisfaction in relation to age.

In his study, Zhongshan [6] also found that work satisfaction among Chinese teachers increased with the increase in age. It is argued that the higher the teacher's age, the higher the level of job satisfaction and the lower the teacher's age, the lower the job satisfaction level [9]. This implies that earlier studies indicate that there is a significant difference in job satisfaction caused by age differences. Additionally, Bennell and Akyeampong conducted a survey on teacher motivation and they found that young Tanzanian teachers were less satisfied with their job than their older counterparts who felt being teachers by profession was a privilege. This implies that teachers differed significantly in job satisfaction with regard to age [10]. 
However, results of the research on job satisfaction that was conducted among primary and secondary school teachers in Greece revealed that there were no significant differences in levels of teachers' job satisfaction with regard to age status. This implies that secondary school teachers in Greece did not differ in their job satisfaction levels in relation to age status.

Teaching experience refers to the number of years a person has served as a teacher. Crossman and Harris call this the "length of service" [7]. According to Koustelios, in Bennell and Akyeampong [10], the teachers with long teaching experience indicated higher levels of job satisfaction with such aspects as pay and supervision. In other words, the level of satisfaction increased with the increase in years of service in the teaching profession. Similarly, Greenberg and Baron contend that employees with many years of service perceived higher job satisfaction than their colleagues [10].

Evidently, adequate empirical research had been conducted to find out age and gender factors influencing teacher's job satisfaction and performance in school in various parts of the world. However, there is limited research on the same in the republic of South Sudan. Therefore, this study sought to determine how demographic factors influence teacher's job satisfaction and performance in the private primary schools in Yei town, South Sudan. The study was guided by the Hierarchy of Need Theory as advanced by Abraham Maslow.

\section{Hierarchy of need theory}

Abraham Maslow, a well-known figure in the area of psychology and a psychologist by profession believes that in the quest to fulfil their needs, individuals behave and exhibit themselves in a certain manner [11].A human being gets satisfaction only when their need is fulfilled. His theory has three assumptions i.e. human needs never end, when one need is fulfilled, the next hierarchy of needs surfaces to be fulfilled and satisfied and lastly human needs can be divided into various levels depending on importance and when the previous level of need is fulfilled, the next level needs to be scaled and fulfilled to derive satisfaction.

Abraham H. Maslow's hierarchical model of human needs can be used to identify the factors affecting job satisfaction. The hierarchy of needs identifies five distinct levels of individual needs. These include physiological, safety, social, esteem and self-actualization needs. Physiological needs represent the most basic of all human needs which are the basic biological needs. These include food, water, shelter and clothing. According to Maslow's theory people would first want to have these needs fulfilled before they move on to the next level of needs [11].Safety needs include the need for security, protection and stability in the physical and interpersonal events of day to day life. According to this theory people want to feel safe, secure, and free from fear. In this regard, they need stability, structure and order. In the workplace, job security and fringe benefits, along with an environment free of violence, fulfils these needs. The theory reiterates that individuals would want to satisfy safety needs only if their basic biological needs have been satisfied.

Self-actualization is the highest motivation level according to Maslow's hierarchy of needs. This involves people striving to actualize their full potential, in order to become more of what they are capable of being. They seek to attain self-fulfilment. In the workplace, people satisfy this need by being creative, receiving training, or accepting challenging assignments [12].

Esteem needs according to Robbinsinclude the need for status, recognition and achievement [13]. People want the esteem of others and they want to be regarded as useful, competent, and important. People also desire self-esteem and need a good self-image. In the workplace, increased responsibility, high status, and recognition for contributions satisfy these needs [13].

Finally, social needs involve the need for love, affection, a sense of belonging in one's relationship with others. Daft also explained this need by writing that it involves the need for friends, family and intimacy for social acceptance and affection from one's peers. In the workplace, this need is satisfied by participation in work groups with good relationships among co-workers and between workers and managers [13].

\section{Materials and Methods}

The study was carried out among private schools in Yei town, South Sudan. Kerlinger [14] defines a research design as the plan, structure, and strategy of investigation conceived so as to obtain answers to research questions and control variance. This study employed a survey design in which quantitative data was collected. The target 
population for the study consisted of 10 private primary schools in Yei town from which 10 head teachers were purposively selected and 100 teachers randomly sampled.

Researchers such as Mugenda and Mugenda [15] have stated that sample size for descriptive studies should be between 10 percent and 20 percent of the population. Kasomo [16] however recommends that researchers use the largest sample possible because statistics calculated from a large sample are more accurate. The sample size for this study was 25 percent as recommended by Kasomo. In order to provide for equal chance for every member in the school to be included, simple random sampling was used. The sample size included all the head teachers in the 10 schools and 50 percent of the 100 teachers in the selected schools, since Neuman [17] indicated that 50 percent is an adequate sample in a descriptive study. The study applied census sampling for all the teachers in the private primary schools in Yei Town, including the head teachers. The total sample size included 10 head teachers and a random sample of 100 teachers from each of the 10 schools to give a total of 110 respondents.

A Self-administered, closed ended questionnaire was used for the study because it had the ability to limit inconsistency and save time as suggested by Amin [18]. The questionnaires were chosen in this study because they produced normative data important for analysis. Collected data was analysed and presented in frequencies and percentages.

\section{Results and Discussion}

The study findings showing demographic characteristics of the respondents and schools in general were presented in tables, charts and bar graphs. Some of these information included gender, age bracket, educational level, length of service, pay, nature of work and organizational culture.

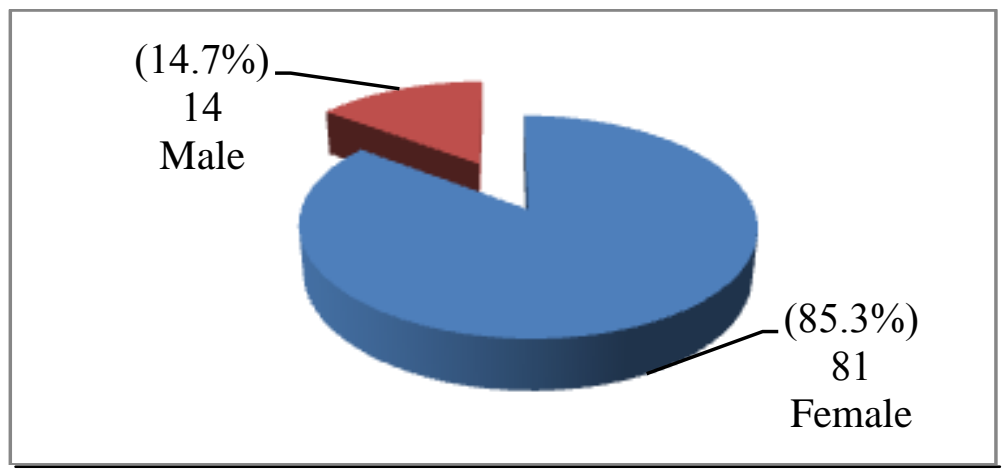

Figure 1. Gender of teachers

The result of the research showed that an overwhelming majority of the respondents (85.3\%) were female while a minimal number $(14.7 \%)$ represented male teachers. This means that men are apprehensive about teaching as a career. While previous studies have indicated a lack of significant difference between the male and female teachers, this study contradicts showing a very high number of females in the teaching profession. Crossman and Harris [7] for instance found out that there was no significant difference, contrary to this study; the two reported that males were slightly more satisfied than females. However, in support of this study are researchers like; Dinham \& Scott [4] and Bishay [5] whose studies indicated that female teachers were more satisfied with their job than male teachers. Could it be that male teachers just record low participation in educational management or are they most placed in higher education levels such as secondary schools and higher learning institutions? This is a question that will demand further research with a focus on such institutions.

This paper also identifies the age bracket of the teachers as categorized into 18-24 years, 25-34 years and 45-54 years. 


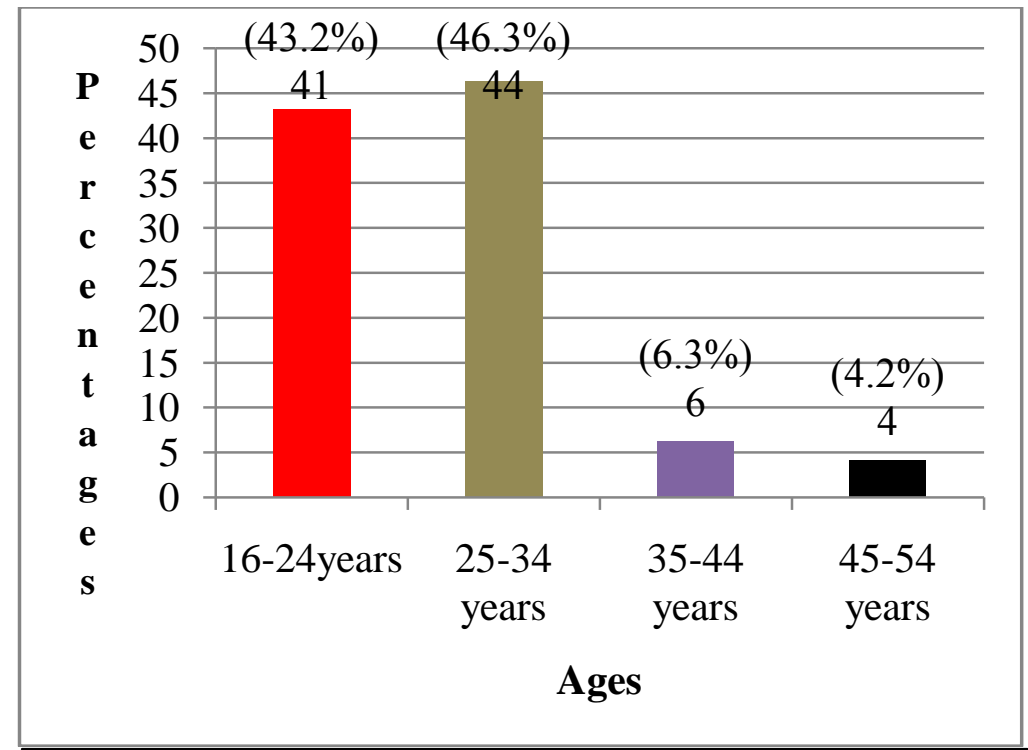

Figure 2: Age bracket of the teachers

From the findings, it is evident that a considerable number of repondents were between 25-34 years which accounts $46.3 \%$ of the teachers interviewed. Then followed closely with those under the age bracket of 18-24 years of age that accounts $43.2 \%$ of the respondents. Even thogh Crossman and Harris [7] explained that age has been associated with job satisfaction, the nature of relationship is not clear. The findings in figure 2 interpret to the fact that private primary schools have very few teachers or none aged over 35 years. It could be explained to mean that such schools employ a majority of young teachers aged 25-34 years and worse even have a representation of below 25 years down to 16 years. Such category can be said to be that just before college or after college.

The educational level of the respondents was also looked into. This was categorized into certificate, diploma and degree levels. The results are as indicated in figure 3.

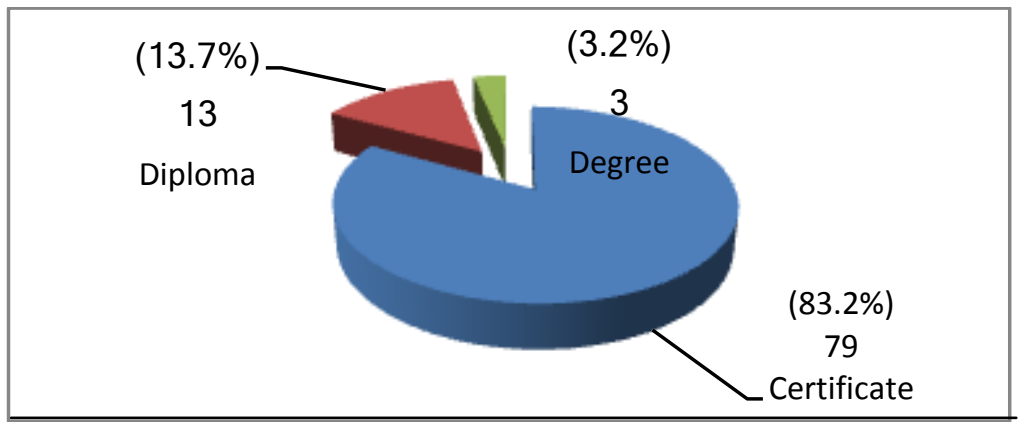

Figure 3: Education level of teachers

The results showed that majority of the teachers 79 (83.2\%) are certificate holders while $13.7 \%$ of them indicated that they are diploma holders. Only $3.2 \%$ of them have attained degrees. The qualification of teachers is not good enough to the majority of private teachers in Yei Town, South Sudan. Length of service also referred to as teaching experience by Crossman and Harris [7] was studied in this paper. It is apparent from figure 4 below that most of the teachers $(60 \%)$ had served between 1-5 years in the teaching career while very few had served for over 15 years. This is indication that most of the teachers leave the teaching profession after only serving for few years. This could also be linked to low levels of job satisfaction at the first few years of service. The teachers with long teaching experience indicated higher levels of job satisfaction with such aspects as pay and supervision [7]. Figure 4 presents the finding of the teachers' length of service. 


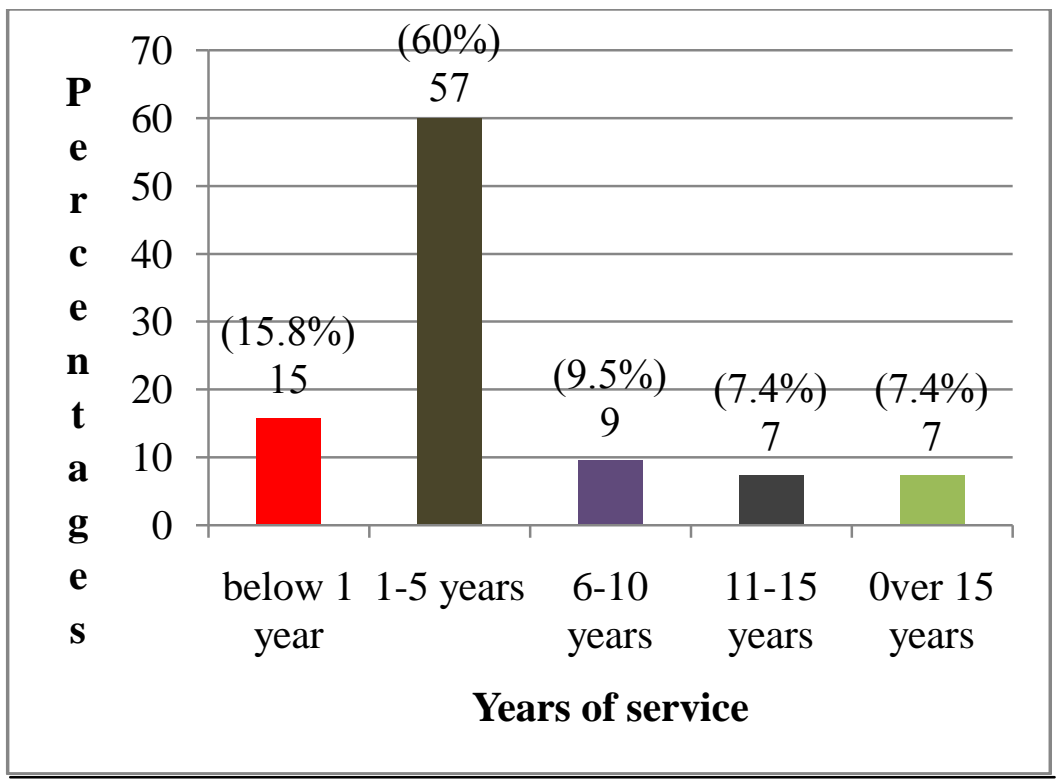

Figure 4. Years of service status of the respondents

To have a deeper understanding of the demographic factors influencing teachers' job satisfaction and performance in private schools in Yei town South Sudan, the pay factor was studied. The teachers were asked to indicate their extent of agreement regarding the various statements on pay factor.

Table 1. Distribution of how pay influence teacher's job satisfaction and performance

\begin{tabular}{llllllllllll}
\hline Pay related statement & SA & & A & & N & & D & & SD \\
& F & $(\boldsymbol{\%})$ & F & $(\boldsymbol{\%})$ & F & $(\boldsymbol{\%})$ & F & $(\boldsymbol{\%})$ & F & $(\%)$ \\
$\begin{array}{l}\text { I feel am paid a fair amount for } \\
\text { the work I do }\end{array}$ & 16 & 16.8 & 36 & 37.9 & 13 & 13.7 & 14 & 14.7 & 16 & 16.8 \\
$\begin{array}{l}\text { I feel satisfied with my } \\
\text { chances for salary increase }\end{array}$ & 23 & 24.2 & 36 & 37.9 & 11 & 11.6 & 17 & 17.9 & 8 & 8.4 \\
$\begin{array}{l}\text { My salary is relevant to my } \\
\text { qualification and experiences }\end{array}$ & 16 & 16.8 & 20 & 21.1 & 11 & 11.6 & 25 & 26.3 & 23 & 24.2 \\
$\begin{array}{l}\text { My salary is competitive and } \\
\text { meet my expectation }\end{array}$ & 5 & 5.3 & 9 & 9.5 & 15 & 15.8 & 42 & 44.2 & 24 & 25.3 \\
\hline
\end{tabular}

A considerable number (37.9\%) stated that they are paid an amount respective to the work they do. This was further supported by $16.8 \%$ of teachers who strongly agreed with the statement. Majority of the teachers (62.1\%) either strongly agreed or agreed with the statement that they feel satisfied with their chances of their salaries being increased. This was however not the case among a number of them (37.8\%) who either strongly disagreed or disagreed to the statement.

Slightly more than a half of the respondents (50.1\%) either strongly disagreed or disagreed to the statement that their pay is relevant to their qualification and experiences. On the other hand, 37.9\% of them either strongly agreed or agreed with the statement. Majority of the teachers (69.5\%) either strongly disagreed or disagreed with the statement that their salary is competitive and meet their expectations. On the hand, a few of them (14.8\%) either strongly agreed or agreed with the statement. 


\section{Conclusion}

The purpose of this study was to identify the demographic factors affecting job satisfaction of private primary school teachers in Yei town of South Sudan. Factors such as age, gender, service length and pay among others have been examined. While some of these factors are significantly related to job satisfaction, there are other factors that affect job satisfaction thus a wider research on them would be necessary.

\section{Recommendation}

Teacher satisfaction has many different facets. For example, while a teacher may be satisfied with her pay she/he may be unhappy about her relationships with colleagues or working conditions. This study has only focused on the demographic factors affecting job satisfaction. Another study can be carried out to gauge other factors influencing job satisfaction and performance.

\section{References}

[1] Shann, M. (2001). Professional commitment and satisfaction among teachers in urban middle schools. The Journal of Educational Research, 92(2), 67-73.

[2] Ololube, P. (2004). Professionalism: An institutional approach to teachers' job effectiveness in Nigerian schools. Paper Presented at the Seventh International LL in E Conference, September 23-25.

[3] Schmidt, S. (2007). The relationship between satisfaction with workplace training and overall job satisfaction. Human Resource Development Quarterly, 18(4), 481-498.

[4] Dinham, S. \& Scott, C. (2000). Moving into the third outer domain of teacher Satisfaction. Journal Educational Administration, 38(4), 379- 396.

[5] Bishay, A. (2006). Teacher motivation and job satisfaction: A study employing the experience sampling method. Journal of Undergraduate Sciences, Vol.3, 147-154.

[6] Zhongshan, Z. (2008). Study of job satisfaction among elementary schools in Shanghai. Chinese Educational Society, 40, (5), 40-46.

[7] Crossman, A. \& Harris, P. (2006). Job satisfaction of secondary school teachers. Educational Management and Leadership, 34(1), 29-46.

[8] Rasku, K. (2003). Job conditions and wellness among finnish upper secondary school teachers. Psychology and Health, 18, (4), 441-456.

[9] Greenberg, J. \& Baron, R. (1995). Behavior in organizations. Englewood Cliffs, New Jersey: Prentice Hall.

[10] Bennell, P. \& Akyeampong, K. (2007). Teacher motivation in Sub-Saharan Africa and South Asia. DFID Department of International Development, 71.

[11] Maslow, A. (1954). Motivation and personality New York: Harper \& Row.

[12] Daft, R.Y. Management. (1997). Orlando, Florida: Harcourt Brace.

[13] Robbins, P. (1998). Organizational behavior. ( $8^{\text {th }}$ Ed.). New Jersey: Prentice Hall.

[14] Kerlinger, F. (1978). Foundations of Behavioral ResearchDelhi, India: Holt, Rinehart and Winston.

[15] Mugenda, O., \& Mugenda, A. (1999). Research Methods: Qualitative and Quantitative Approaches. Nairobi: Acts Press.

[16] Kasomo, D. (2007). Research Methods in Humanities and Education Eldoret: Zapf Chancery.

[17] Neuman, W. (2000). Social Research Methods: Qualitative and Quantitative Approaches (4 ${ }^{\text {th }}$. Ed.). Boston: Allyn and Bacon.

[18]Amin, M. (2004). Foundations of Statistical Inference for Social Science Research. Makerere University, Kampala Uganda. 